\title{
The impact of foliar nickel fertilization on urease activity in pecan trees
}

\author{
D. L. Ojeda-Barrios ${ }^{1 *}$, E. Sánchez-Chávez ${ }^{2}$, J. P. Sida-Arreola ${ }^{1}$, R. Valdez-Cepeda ${ }^{3}$, M. \\ Balandran-Valladares ${ }^{1}$ \\ ${ }^{1}$ Facultad de Ciencia Agrotecnológicas, Universidad Autónoma de Chihuahua, Ciudad Universitaria \\ s/n. Chihuahua, Chih. México C.P. 31310. ${ }^{2}$ Centro de Investigación en Alimentación y Desarrollo A.C. \\ Coordinación Delicias.. Fraccionamiento Vencedores del Desierto. Cd. Delicias, Chihuahua, México. \\ C.P.33089.. E mail:esteban@ciad.mx 33Universidad Autonoma de Chapingo, Centro Regional Universitario \\ Centro-Norte. Calle Cruz del Sur No. 100, Col. Constelacion. CP 98085, El Orito, Zacatecas, Zac., México. \\ *Corresponding author:dojeda@uach.mx
}

\begin{abstract}
The aim of the present work is to analyze the effect of different foliar products of nickel $(\mathrm{Ni})$ on the nutrient concentration, chlorophyll content, and enzymatic activity of urease as the possible bioindicator of the levels of $\mathrm{Ni}$ in the leaves of pecan [Carya illinoinensis (Wangenh.) K. Koch]. The experiment consisted of the foliar application of Ni to pecan cv. Western Schley, using two commercial products: Nickel Plus ${ }^{\circledR} \mathrm{T}_{1}$ and Speedfol ${ }^{\mathrm{TM}}$ Pecano $\mathrm{T}_{2}$, and a control $\mathrm{T}_{0}$ received no Ni treatment. The following variables were evaluated: the total chlorophyll concentration, the concentration of macro- and micronutrients including $\mathrm{Ni}$, and the activity of urease. The results demonstrated that the pecan trees treated with $\mathrm{Ni}$ increased in the concentration of this element and that the product Nickel Plus ${ }^{\circledR} \mathrm{T}_{1}$ increased by $41.24 \%$ with respect to control. The foliar application of $\mathrm{Ni}$ led to significant differences in the foliar concentrations of $\mathrm{N}, \mathrm{P}, \mathrm{K}, \mathrm{Ca}, \mathrm{Mg}, \mathrm{Fe}, \mathrm{Mn}, \mathrm{Cu}, \mathrm{Zn}$, and Ni. Chlorophyll showed a significant reaction to the foliar application of Ni. The enzymatic activity of urease proved to be positively related to the foliar level of $\mathrm{Ni}$, and thus could be considered a good physiological bioindicator of the nutritional state of foliar $\mathrm{Ni}$ in the leaflets of the pecan tree.
\end{abstract}

Keywords: Carya illinoinensis, metal, micro nutrients

\section{Introduction}

The pecan tree [Carya illinoinensis (Wangenh.) $\mathrm{K}$. Koch] has increased in crop profitability in recent years as well as socioeconomic importance in northern Mexico (Ojeda-Barrios et al., 2014). The nutrition of this plant is a major topic in orchard management.
Nickel (Ni) has been recognized since 2004 by the Official American Association of Plant Nutrient Control as an essential element in plants (Wood et al., 2004a) because of its relationship with urease as a catalyzer or inhibitor and constituent of this 
enzyme (Bai et al., 2007a). For plant metabolism, Ni is required in quantities of less than $0.001 \mathrm{mg} \mathrm{kg}^{-1}$, dry weight. Several works have demonstrated that $\mathrm{Ni}$ is required for seed viability in barley (Hordeum vulgare) (Wagle et al., 2011). This proposal has been strengthened by field observations of growth and responses to foliar applications of $\mathrm{Ni}$ in crops as diverse as wheat (Triticum aestivum), potato (Solanum tuberosum), and broadbean (Vicia faba) (Rahmana et al., 2005). Despite the studies made, little information is available on the metabolism or the metabolic function of $\mathrm{Ni}$, compared with other microelements. To date, the activation of urease appears to be the only enzymatic function of Ni in higher plants (Seregin and Kozhevnikova, 2006). Urease catalyses the hydrolysis of urea $\left[\mathrm{CO}\left(\mathrm{NH}_{2}\right)_{2}\right]$, a reaction that splits the molecule into ammonium $\left(\mathrm{NH}_{3}\right)$ and carbon dioxide. Ni deficiency inhibits the action of urease, leading to the accumulation of urea, which can provoke the appearance of necrotic spots on the leaves (Reuter, 2005; Wood, 2006). In addition, this deficiency can interrupt the metabolism of ureides, amino acids, and organic acids, and can accumulate oxalatic and lactic acids. Urease contains two $\mathrm{Ni}$ ions at its active site (Palacco et al., 2013). Evidence indicates that the transporter species of ureides, as in walnut trees, have a higher requirement of $\mathrm{Ni}$ than do transporter species of amides, thus increasing the possibility that the ureide transporters can have enzymes, except urease, which requires $\mathrm{Ni}$ for its activation or to intensify its activities (Wood, 2006). Under pecan cultivation, severe Nideficiency can cause a growth abnormality (i.e. mouse ear) and interfere with transplants in orchards (Pradeep et al., 2011). Such deficiency also interrupts $\mathrm{N}$ and $\mathrm{C}$ metabolism during leaf expansion (Bai et al., 2007a). The necrotic spots associated with $\mathrm{Ni}$ deficiency correspond to the accumulation sites of urea or oxalatic and lactic acids, indicating that changes also occur in $\mathrm{C}$ metabolism, in particular during the reduction of respiration (Wite Claus-Peter, 2011). Initially, this disorder (mouse ear) was attributed to various causes, such as cold damage, viral infections, or $\mathrm{Mn}$ or $\mathrm{Cu}$. The foliar analysis of healthy leaves compared with affected ones revealed that the symptoms are provoked by Ni deficiency caused by low contents of this element or induced by excessive zinc in the soil (Wood et al., 2004b).

Another study found that pecan trees transport mainly $\mathrm{N}$ such as ureides at the onset of spring and that the nutritional state of $\mathrm{Ni}$ in these trees affects the metabolism of ureides and amides as well as sap composition in the xylem. Meanwhile, Ni deficiency quantitatively affects the composition of xanthine in the sap, alantoic acid, asparagine, citruline, and $\beta$-phenyletylamine in the sap of the xylem in spring, and interrupts ureide catabolism and the urea-metabolism cycle (Wood et al., 2004a). The effect observed of $\mathrm{Ni}$ on $\mathrm{N}$ metabolism constitutes evidence that $\mathrm{Ni}$ nutrition is more important for the management of $\mathrm{N}$ than for the transport of ureides in crops (Bai et al., 2013).

The aim of the present work was to assess the impact of two commercial foliar Ni fertilizers on the leaf mineral composition, including $\mathrm{Ni}$, chlorophyll content and urease activity in the leaflets of the pecan tree.

\section{Materials and Methods}

\subsection{Description of the study area}

The study was conducted in Delicias, Chihuahua (Mexico), during the 2010 vegetative cycle. The orchard is located at $28^{\circ} 11^{\prime}$ latitude norths, $105^{\circ}$ $28^{\prime}$ longitude west, and an altitude of $1170 \mathrm{~m}$, with $336.5 \mathrm{~mm}$ of annual precipitation. It is an arid region with a mean temperature of $18.6^{\circ} \mathrm{C}$. The orchard was on a calcareous soil (Domino silt loam, Xerollic Calciorthid), has an arable layer of 0-35 $\mathrm{cm}$ with a 
$\mathrm{pH}$ of 7.25 in $1: 1$ soil: water, $1.2 \%$ organic matter, $10.0 \%$ total $\mathrm{CaCO}_{3}, 8.8 \mathrm{mg} \cdot \mathrm{kg}^{-1} \mathrm{NO}_{3}^{-}$, and 0.48 $\mathrm{mg} \cdot \mathrm{kg}^{-1}$ DTPA-extractable Zn (Rivera-Ortiz et al., 2003). The orchard consisted of 15 -year-old pecan (70 trees $\cdot \mathrm{ha}^{-1}$ ). The pecan trees, cv. Western Schley, grafted to a native rootstock, were 25 years old. The planting scheme was $12 \times 12 \mathrm{~m}$ with a density of 70 trees per ha. Three treatments were evaluated, Two commercial Ni-based foliar products were applied on 25 May and 24 June 2010: Nickel Plus ${ }^{\circledR} \mathrm{T}_{1}$ (total N 5\%, S 3\%, and Ni 5.4\%) (N 2.85, S 1.87 and 0.73 $\mathrm{mM}$ ) and Speedfol ${ }^{\mathrm{TM}}$ PecanoT $_{2}$ (N 5\%, P 12\%, K $18 \%, \mathrm{Mg} 4.2 \%$, and Ni 5.4\%) ( N 2.39, P 2.51, K 0.95, $\mathrm{Mg} \mathrm{1.15}$, and $\mathrm{Ni} 0.76 \mathrm{mM}$ ), and a Control $\mathrm{T}_{0}$. The application rates were $2000 \mathrm{~mL}$ for Nickel Plus ${ }^{\circledR} \mathrm{T}_{1}$ and $670 \mathrm{~g}$ for Speedfol Pecano ${ }^{\mathrm{TM}} \mathrm{T}_{2}$. A randomized block design was used with four replications per treatment. The experimental unit was one tree. In all formulations, $0.1 \%$ urea was added as transporter ion and $100 \mathrm{mg} \cdot \mathrm{L}^{-1}$ Tween 20 (Thermo Scientific, Illinois, USA) was used as a surfactant. The $\mathrm{pH}$ of the solutions was adjusted with sulfuric acid to 6.5 , a $\mathrm{pH}$ that is thought to facilitate foliar uptake of metal formulations (Ojeda-Barrios et al., 2014).

Trees were sprayed between 7:00 and 9:00 a.m. using a mist sprayer PTO SNT-500-30E, covering the entire tree canopy to the drip point.

\subsection{Orchard management}

The trees were fertilized once with 120-80-80 NPK using ammonium sulfate (20.5\% of $\mathrm{N})$, diammonium phosphate $\left(46 \%\right.$ of $\left.\mathrm{P}_{2} \mathrm{O}_{5}\right)$, and potassium sulfate $(50 \%$ of $\mathrm{K}_{2} \mathrm{O}$ ), respectively. Fertilizers were broadcasted on 30 March 2010 and the area was immediately raked and then irrigated. Trees were flood irrigated, using 120 to $140 \mathrm{~mm}$ of water, every 20 days from March to the end of October. The most common pests were yellow aphid (Monelia caryella) and the hickory shuckworm
(Laspeyresia caryana), while the most common disease was downy spot (Mycosphaerella carygena). Due to the low incidence, no control was applied.

\subsection{Foliar sampling}

Approximately 30 pairs of leaflets were collected five times during the growing season (18 May, 9 June, 12 July, 23 August, 6 September, and 4 October 2010) from the mid-canopy of each tree. Leaflets were collected mixing samples from the four cardinal directions and from vegetative and fruiting shoots. Six foliar samplings were taken: 18 May, 9 June, 12 July, 23 August, 6 September, and 4 October 2010. The leaves were sampled from the middle of the branch selected while the leaf sample was taken from the middle part of the leaf, taken from 30 pairs of leaflets per sample. The different samplings were used to evaluate the variables of total chlorophyll concentration, greenness of the leaf by the Minolta SPAD 502 chlorophyll meter, and the foliar concentrations of $\mathrm{N}, \mathrm{K}, \mathrm{Ca}, \mathrm{Mg}, \mathrm{Fe}, \mathrm{Cu}, \mathrm{Mn}$, and $\mathrm{Ni}$, as well as urease activity.

The samples collected were analyzed in the laboratory of Plant Nutrition del Centro de Investigación en Alimentación y Desarrollo A.C. (CIAD-Delicias). The samples were washed with running water, immediately afterwards with running water plus $\mathrm{HCl} 4 \mathrm{~N}$ and then were rinsed with tap water and with deionized water. The leaves were left to drain and were dried at room temperature and finally were dried in a stove at $60^{\circ} \mathrm{C}$ for $24 \mathrm{~h}$ and milled using a 20-mesh screen (Ojeda-Barrios et al., 2012). Nickel, $\mathrm{Zn}, \mathrm{Fe}, \mathrm{Mn}, \mathrm{Cu}, \mathrm{K}, \mathrm{Ca}$, and $\mathrm{Mg}$ were determined by triacid digestion $\left(\mathrm{HNO}_{3}, \mathrm{HClO}_{4}\right.$, and $\mathrm{H}_{2} \mathrm{SO}_{4}$ in the ratio 10:1:0.25), and with an atomic absorption spectrophotometer (Thermo Scientific Analysis 3000) (Smith et al., 2004). Nitrogen level was determined by the micro-Kjeldahl method (Wagle et al., 2011). 


\subsection{Determination of total chlorophyll}

The total chlorophyll concentration was quantified by extraction with methanol and reading the absorbance. For this, $60 \mathrm{mg}$ of petiolules of $5 \mathrm{~mm}$ in diameter were weighed, placed in test tubes with $5 \mathrm{ml}$ of methanol, and left $24 \mathrm{~h}$ or more until total discoloration of the plant material. The process was made at ambient temperature in darkness. Afterwards, the absorbance was read in $652 \mathrm{~nm}$, the total chlorophyll content being expressed in $\mathrm{mg} \cdot \mathrm{kg}^{-1}$ (Ojeda-Barrios et al., 2012).

\subsection{Leaf greenness (SPAD units)}

With the Minolta SPAD-502 chorophyll-meter, 20 readings were taken for the chlorophyll from pecan leaflets, and in the middle part of the tree, in the current-year growth, the third leaflet of the leaf was taken, making sure that it was healthy, avoiding veins (especially the central one).

\subsection{Urease activity (E.C. 3.5.1.5)}

For the extraction of the urease activity, $0.5 \mathrm{~g}$ of petiolules of $3 \mathrm{~mm}$ in diameter were weighed and placed in test tubes with $5 \mathrm{ml}$ of $\mathrm{H}_{2} \mathrm{PO}_{4} \mathrm{mM}$ at $\mathrm{pH}$ 7.5 in the presence of at $5 \%$ with urea at $0.2 \mathrm{M}$ and without urea. This was placed in a vacuum for $5 \mathrm{~min}$ at $30 \mathrm{mmHg}$ and afterwards incubated in a double boiler at $100^{\circ} \mathrm{C}$ for $3 \mathrm{~min}$. An extract was used to quantify the ammonium released, using one $\mathrm{mL}$ of the extract $6 \mathrm{~mL}$ of $\mathrm{KH}_{2} \mathrm{PO}_{4}, \mathrm{mM}$ at $\mathrm{pH} 7.5$, $4 \mathrm{~mL}$ salicylate-nitroprussiate- $\mathrm{Na}$ at $15 \%$, and 2 $\mathrm{mL}$ of $\mathrm{Na}$ hypochlorite at $5.35 \%$. The extract was incubated for $20 \mathrm{~min}$ at $37^{\circ} \mathrm{C}$ in darkness and finally the process was carried out at room temperature in darkness. Afterwards, the absorbance was read at 560 $\mathrm{nm}$, from the samples without urea, and with urea against a pattern of $\mathrm{NH}_{4}^{+}$. The enzymatic activity was expressed as $\mu \mathrm{mol}$ of $\mathrm{NH}^{4+}$ formed $\min ^{-1} \mathrm{~g}^{-1} \mathrm{p}$. f. (Palacco et al., 2013).

\subsection{Statistical analysis}

All the data were submitted to an analysis of variance using the completely random model with a total of 3 treatments and 4 replicates. The differences between the means of the treatments were compared using the LSD test at 95\% using SAS (2007). Finally, the significance levels were represented by $*$ at $\mathrm{P}<0.05$ and N.S. for not significant).

\section{Results and Discussion}

\subsection{Foliar nutritional concentration}

Nutritional analysis assesses the state of nutrition of a crop and evaluates the availability of reserves in the plant (Wood et al., 2004c). In the present study, significant differences were found in the foliar concentration after the application of the Ni-based products Nickel Plus ${ }^{\circledR} \mathrm{T}_{1}$ and Speedfol ${ }^{\mathrm{TM}}$ Pecano $\mathrm{T}_{2}$, for macronutrients (N, P, K, Ca, and $\mathrm{Mg}$; Table 1) as well as micronutrients ( $\mathrm{Fe}, \mathrm{Mn}, \mathrm{Cu}, \mathrm{Zn}$, and $\mathrm{Ni}$; Table 2) (Pradeep et al., 2011). The values found for these nutrients were within the sufficiency range (Medina, 2004). It has been reported that $\mathrm{Ni}$ has a synergetic relationship with $\mathrm{Fe}, \mathrm{Zn}, \mathrm{Cu}$, and $\mathrm{Mn}$ (Wood et al., 2004a) as well as with $\mathrm{N}$ and $\mathrm{P}$ through the interaction of $\mathrm{Ni}$ in the biochemical pathways that are critical for budding, canopy formation, and fruit formation in pecan trees (Wood et al., 2004b). 
Table 1. Effect of the application of Nickel Plus ${ }^{\circledR}$ and Speedfol Pecano ${ }^{\mathrm{TM}}$ on the macronutrient concentrations in pecan trees. The data are means \pm standard error $(n=4)$.

\section{Macronutrients (g.kg $\left.{ }^{-1}\right)$}

\section{Treatments of Nickel}

\section{$\begin{array}{llllll}\mathbf{N} & \mathbf{P} & \mathrm{K} & \mathrm{Ca} & \mathrm{Mg}\end{array}$}

\begin{tabular}{|c|c|c|c|c|c|}
\hline & $\mathbf{N}$ & P & $\mathbf{K}$ & $\mathrm{Ca}$ & $\mathrm{Mg}$ \\
\hline Control $\mathrm{T}_{0}$ & $2.14 \mathrm{~b} \pm 0.12$ & $0.157 \mathrm{a} \pm 0.04$ & $1.344 a \pm 0.05$ & $0.775 \mathrm{a} \pm 0.01$ & $0.411 \mathrm{a} \pm 0.03$ \\
\hline Nickel Plus $\left(\mathrm{T}_{1}\right.$ & $2.39 \mathrm{~b} \pm 0.14$ & $0.154 \mathrm{a} \pm 0.03$ & $1.425 \mathrm{a} \pm 0.07$ & $0.726 a \pm 0.02$ & $0.365 \mathrm{~b} \pm 0.03$ \\
\hline Speedfol $^{\mathrm{TM}}$ PecanoT $_{2}$ & $2.26 a b \pm 0.09$ & $0.147 \mathrm{a} \pm 0.02$ & $1.438 \mathrm{a} \pm 0.04$ & $0.633 \mathrm{a} \pm 0.02$ & $0.432 \mathrm{a} \pm 0.04$ \\
\hline Significance & * & ns & * & * & * \\
\hline
\end{tabular}

tData are means $(\mathrm{n}=4)$ and the significance level is represented by * at $\mathrm{P} \leq 0.05,{ }^{* *}$ at $\mathrm{P} \leq 0.01, * *$ at $\mathrm{P} \leq 0.001$, and * at $\mathrm{P}<0.05$ (ns being not significant).

Table 2. Effect of the application of Nickel Plus ${ }^{\circledR}$ and Speedfol Pecano ${ }^{\mathrm{TM}}$ on the micronutrient concentration in pecan trees. The data are means \pm standard error $(n=4)$.

\section{Treatments of Nickel}

Micronutrients ( $\left.\mathrm{mg} \mathrm{kg}^{-1}\right)$

\begin{tabular}{|c|c|c|c|c|c|}
\hline & $\mathbf{C u}$ & $\mathbf{F e}$ & Mn & $\mathrm{Zn}$ & $\mathbf{N i}$ \\
\hline Control $\mathrm{T}_{0}$ & $\$ 9.89 \mathrm{a} \pm 0.63$ & $56.79 \mathrm{a} \pm 3.06$ & $55.61 \mathrm{a} \pm 3.91$ & $56.94 a \pm 2.54$ & $3.38 \mathrm{~b} \pm 0.04$ \\
\hline Nickel Plus $\mathbb{R} \mathrm{T}_{1}$ & $10.75 \mathrm{a} \pm 0.57$ & $56.96 \mathrm{a} \pm 4.60$ & $67.01 \mathrm{a} \pm 7.63$ & $60.62 \mathrm{a} \pm 1.71$ & $5.94 a \pm 0.06$ \\
\hline Speedfol $^{\mathrm{TM}}$ Pecano $_{2}$ & $11.16 \mathrm{a} \pm 0.40$ & $57.96 \mathrm{a} \pm 4.47$ & $60.65 a \pm 8.40$ & $58.54 \mathrm{a} \pm 3.51$ & $4.79 \mathrm{ab} \pm 0.10$ \\
\hline Significance & * & ns & $* *$ & ns & $*$ \\
\hline
\end{tabular}

Data are means $(\mathrm{n}=104)$ and the significance level is represented by * at $\mathrm{P} \leq 0.05$, ** at $\mathrm{P} \leq 0.01, * *$ at $\mathrm{P} \leq 0.001$, and * at $\mathrm{P}<0.05$ (ns being not significant).

\subsection{Foliar nitrogen}

Nitrogen is the element most required by nut trees, as no other nutrient is as determinant of vigor, yield, and nut quality (Smith et al., 2004). In the form of urea, $\mathrm{N}$ is not available for metabolism by the plant, unless hydrolyzed to $\mathrm{NH}_{3}$ and $\mathrm{CO}_{2}$ by urease. In this study, the product Nickel Plus ${ }^{\circledR} \mathrm{T}_{1}$ 0.73.mM boosted
$\mathrm{N}$ status in comparison to Speedfol ${ }^{\mathrm{TM}}$ Pecano $\mathrm{T}_{2}$ $0.76 \mathrm{mM}$ and control $\mathrm{T}_{0}$ (Table 1). The values found in the two treatments in which $\mathrm{Ni}$ was applied were higher and control lower than the sufficiency range (Medina, 2004). The metabolism of $\mathrm{N}$ is affected by ureide catabolism, amino acid metabolism, and the 
intermediary cycle of ornithine, while it affects the citric acid cycle of carbonate metabolism. Perhaps determination of $\mathrm{N}$ fractions could be better to understand $\mathrm{Ni}$ effect. This indicates that Ni deficiency can potentially influence the metabolism and the physiology of $\mathrm{N}$ in the plant (Bai et al., 2007a). The reaction catalyzed by ureases is essential so that $\mathrm{N}$ from urea is accessible to plants (Wood, 2006; Ruter, 2005). In this study, $\mathrm{Ni}$ and urease presented a value significative of $\mathrm{r}^{2}=0.6468$

\subsection{Foliar zinc}

Zinc is one of the most nutrient required by pecan trees. Zinc deficiency causes yellowing between foliar veins, which has been related to the stabilizing role of $\mathrm{Zn}$ on the chlorophyll molecule (Nuñez-Moreno et al., 2009; Ojeda-Barrios et al., 2012; Ojeda-Barrios et al., 2014). The results found in foliar sprays with $\mathrm{Ni}$ were highly significant for the case of foliar-Zn content (Table 2). Nickel Plus ${ }^{\circledR} \mathrm{T}_{1}$ had the higher $\mathrm{Zn}$ leaf level with $60.62 \mathrm{mg} \mathrm{kg}^{-1}$, which proved to be deficient (Medina, 2004). The $\mathrm{Zn}$ values found revealed a possible interaction with $\mathrm{Ni}$, as for other nutrients such as $\mathrm{Fe}, \mathrm{Cu}$, and $\mathrm{Mn}$ (Wood, 2006).

\subsection{Foliar-Ni dynamics}

Nickel is essential for growth, productivity, and yield in the pecan tree (Wood et al., 2004a). In the present study, it was found that the Ni-based products had a direct effect on the foliar Ni content in comparison with control (Figure 1ab show Urease level), underscoring that the product Nickel Plus ${ }^{\circledR} \mathrm{T}_{1}$ improved the foliar $\mathrm{N}$ in comparison with the product Speedfol ${ }^{\mathrm{TM}}$ Pecano $\mathrm{T}_{2}$ and control $\mathrm{T}_{0}$. This makes the product more effective to prevent mouse ear in the pecan tree (Wood et al., 2004b). It is important to mention that the values found even for the product that achieved the best results were lower than those reported in Arizona (11.4 mg.kg-1 ) (Pond et al., 2006). In addition, it was found that the treated leaflets of the plants presented a concentration of $7 \mathrm{mg} \mathrm{kg}^{-1}$, while the affected leaflets with mouse ear symptoms had a concentration of $0.5 \mathrm{mg} \mathrm{kg}^{-1}$, this coinciding with reports elsewhere (Wood et al., 2004a). The response of these effects was due possibly to the fact that Ni was transported rapidly to the metabolically active sites, bringing about multiple effects in growth, as previously established (Wood et al., 2004c). In nutritional dynamics, it was found that the product Nickel Plus ${ }^{\circledR}$ T1 applied on 25 May and 24 June increased the Ni concentration, as reflected in Figure $1 \mathrm{~cd}$. The highest foliar concentration corresponded to Nickel Plus ${ }^{\circledR} T_{1}$ on the sampling dates of 9 June and 12 July, after the foliar applications of $\mathrm{Ni}$, in which this nutrient was demanded because the tree had entered the rapid growth phase of the fruit. Finally, there was an increase in the Ni concentration on 6 September, possibly related to the retranslocation of nutrients in the ecodormancy in deciduous trees. Ni is critical for the tree during the first growth stages in spring in order to break down the urea into ammonium ions in order to produce amino acids for incorporation into protein structures, enzymes, and nucleic acids (Wood et al., 2004c). Yield, nut weight and nut quality were unaffected by treatments (not shown) 

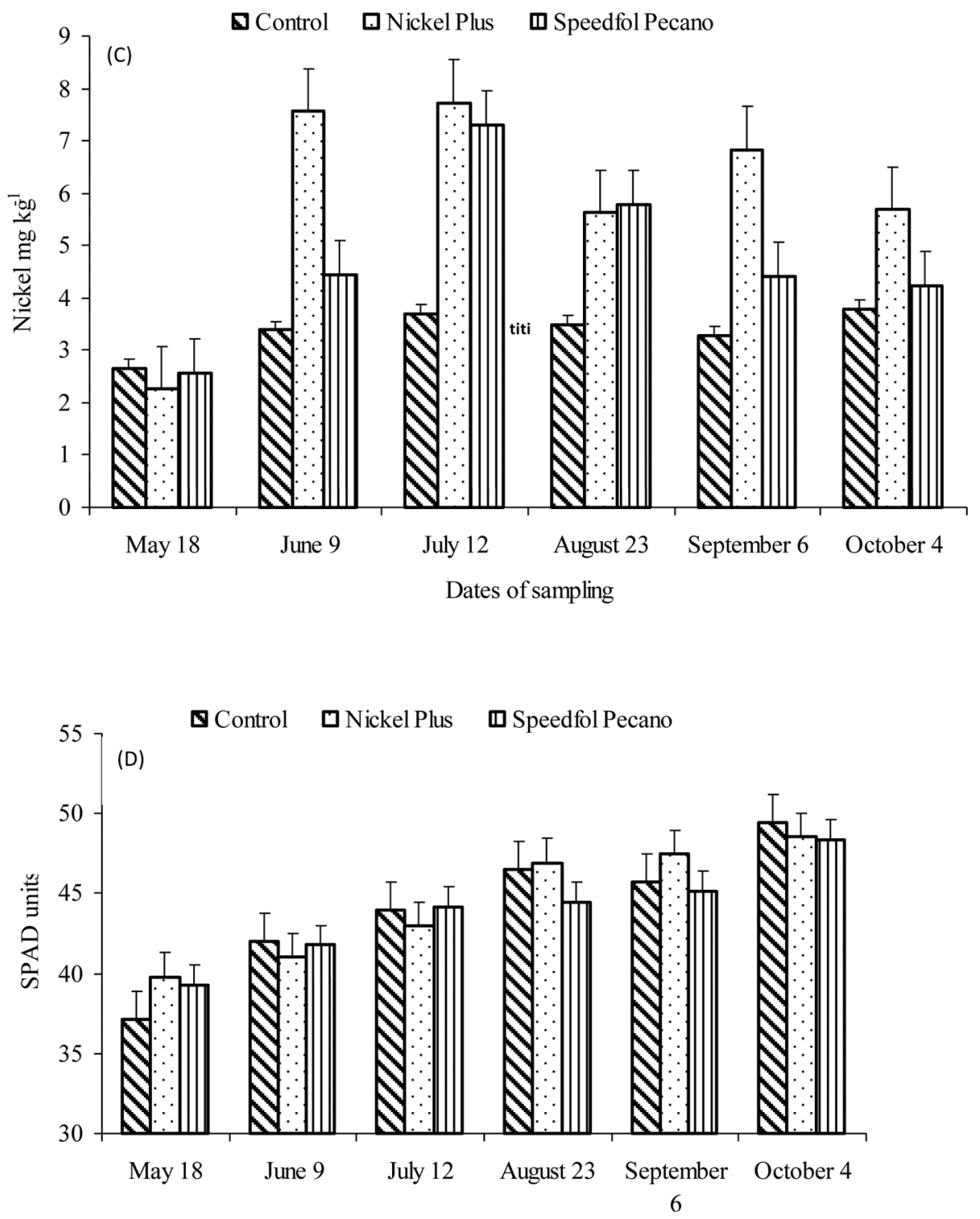

Figure 1ab. Effect of the application of three treatments of Nickel on the nutritional dynamics of foliar; A) Urease Activity; B) Total Nitrogen; C) Foliar Nickel and D) SPAD Units in pecan trees. 

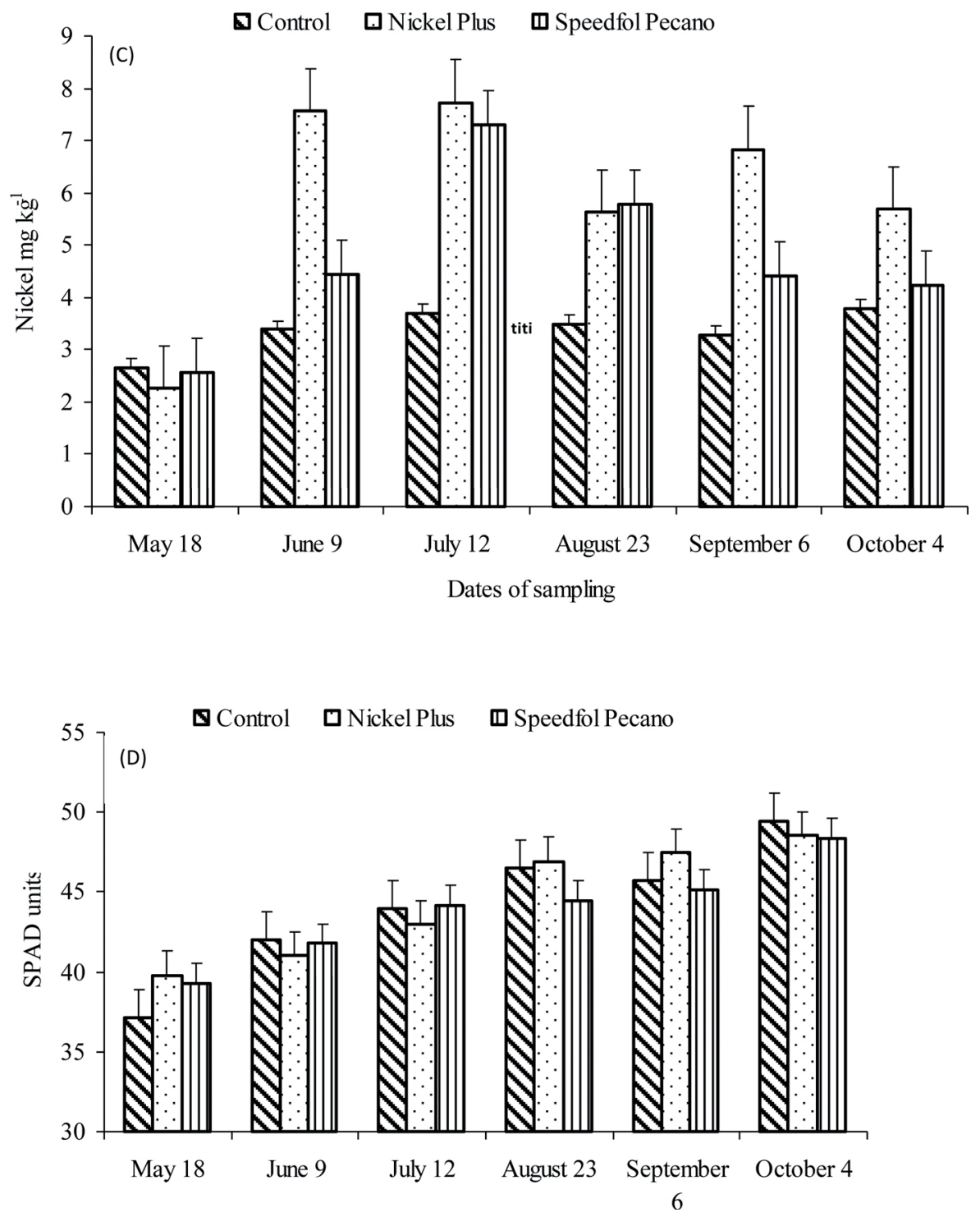

Figure 1cd. Effect of the application of three treatments of Nickel on the nutritional dynamics of foliar; A) Urease Activity; B) Total Nitrogen; C) Foliar Nickel and D) SPAD Units in pecan trees. 


\subsection{Urease activity}

The importance of urease is linked to the hydrolysis of urea for the metabolism of $\mathrm{N}$ and the activation of this enzyme is the only enzymatic function involving $\mathrm{Ni}$ in higher plants (Witte Claus-Peter, 2011). Previous results have indicated that the $\mathrm{Ni}$ applications stimulate the activity of urease in pecan leaves (Bai et al., 2013). In our study, we found statistical differences in urease activity after the application of the Ni-based products in pecan trees (Figure 1ab), findings reaffirmed by Bai et al., 2007b(). The increases in urease by the products Nickel Plus ${ }^{\circledR}$ T1 and Speedfol ${ }^{\mathrm{TM}}$ Pecano $\mathrm{T}_{2}$ with respect to control were $32 \%$ and $21 \%$, respectively. Thus, the foliar application of $\mathrm{Ni}$ increased the activity of urease in the leaf, activating and preventing the accumulation of foliar urea (Wood et al., 2004c). The relation between Ni and urease has an $\mathrm{r}^{2}=0.6468$ (Figure 2). The use of Ni can improve the activity of urease and thereby improve $\mathrm{N}$ nutrition in pecan (Wood et al., 2004c). The evidence indicates that the transporter species of ureides, such as those contained in the pecan tree possess high Ni requirements, more than the transporter species of amides, and therefore urease can be used as a bioindicator of the Ni concentration in the pecan tree (Wood, 2006). In the present study, a higher urease activity was found on the sampling dates of 9 June and 6 September, proportional to the Ni concentration (Figure 1cd). The results indicate that the Ni applications augmented urease activity, preventing urea accumulation in the leaflets of the pecan tree (Wagle et al., 2011). For the June sampling date, the tree was in rapid fruit growth while on the September date the tree was at the fruit-maturation stage, requiring greater activity of $\mathrm{N}$ metabolism related to ureide production (Redjela et al., 2010)

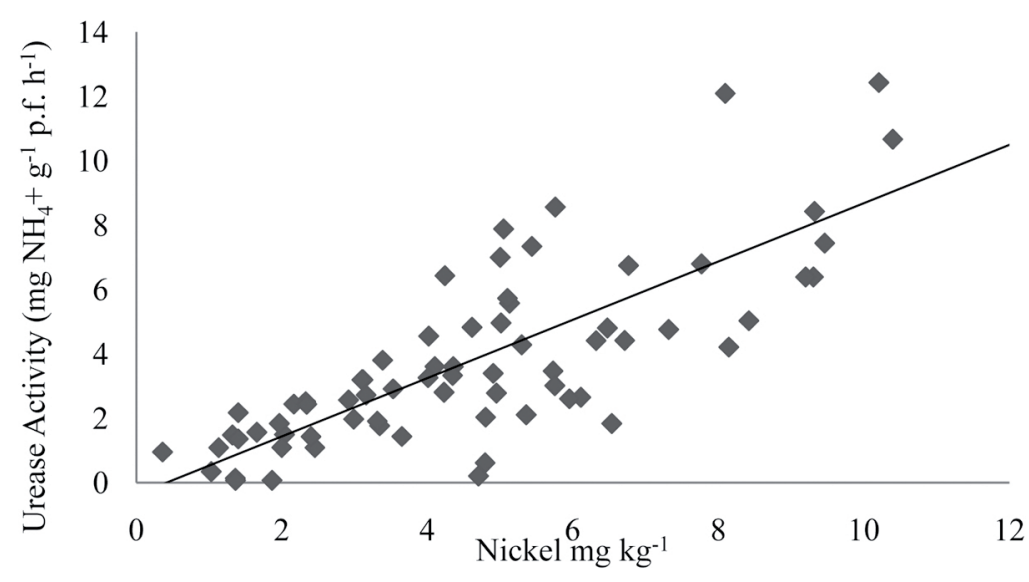

Figure 2. Corretation between Urease and Nickel concentration of treatments during vegetative cycle. $\mathrm{Y}=0.6468 \mathrm{x}+0.3764 . \mathrm{R}^{2}=0.6468$. 


\subsection{Total Chlorophyll}

Total chlorophyll is an indicator of the nutritional state of crops and, for the pecan tree, has been related to the contents of $\mathrm{N}$ and $\mathrm{Zn}$ (Ojeda-Barrios et al., 2009; De La O-Quezada et al., 2011). The values found for chlorophyll by SPAD 502 significantly differed due to the effect of foliar application of $\mathrm{Ni}$, the mean being 44.38. In this sense, the best treatment was the product Nickel Plus ${ }^{\circledR} \mathrm{T}_{1}$, with a $\mathrm{Ni}$ concentration of $5.94 \mathrm{mg} \mathrm{kg}^{-1}$. For chlorophyll determined by methanol, the values reflected that there was significance only for Speedfol ${ }^{\mathrm{TM}}$ Pecano $\mathrm{T}_{2} \mathrm{mM}$ with a Ni concentration of $4.79 \mathrm{mg} \mathrm{kg}^{-1}$, this being the best treatment, while the mean for the total chlorophyll concentration was $22.76 \mathrm{mg}$ $\mathrm{mL}^{-1}$. The above findings are shown in Figure 2. It bears highlighting that the product Nickel Plus ${ }^{\circledR} \mathrm{T}_{1}$ was considered in concentrations of sufficiency, this coinciding with previous reports (Ojeda-Barrios et al., 2012).

\section{Conclusions}

In short, considering our overall results, we conclude that the foliar applications of $\mathrm{Ni}$ increased the foliar $\mathrm{Ni}$ concentration in the leaves of Western Schley pecan trees, the product Nickel Plus ${ }^{\circledR T_{1}}$ being the better choice to supply Ni to the trees. On the other hand, Ni deficiency can have potentially harmful consequences for the metabolism and physiology of pecan trees. The application of the Ni products exerted a positive effect on the nutritional state of foliar $\mathrm{N}$, indicating a synergism between $\mathrm{Ni}$ and $\mathrm{N}$. Urease activity proved to be positively related to the foliar level of $\mathrm{Ni}$, and therefore can be considered a good physiological bioindicator of the nutritional state of foliar Ni in the leaflets of pecan.

\section{Acknowledgments}

This study was granted by Asociación Local de Productores de Nogal y Nuez de Delicias, Chihuahua. México.

\section{References}

Bai, C., Liping L., Wood B. 2013. Nickel affects xylem Sap RNase a and converts RNase A to a urease. Plant Biology 13(207) doi: 10.1186/14712229-13-207

Bai, C., Reilly, C.C. Wood, B.W. 2007a. Nickel deficiency affects nitrogenous forms and urease activity in spring xylem sap of pecan. J. Amer. Soc. Hort. Sci. 132, 302-309.

Bai, C., Reilly, C.C., Wood, B.W. 2007b. Insights into the nutritional physiology of nickel. Acta Hort. 772, 365-368. Doi: 10.17660/ ActaHortic.2008.772.62.

De La O-Quezada, A., Ojeda-Barrios, D.L., Hernández-Rodríguez, O.A., Sánchez-Chávez, E. a Martínez-Téllez, J. 2011. Biomasa, prolina y parámetros nitrogenados en plántulas de nogal bajo estrés hídrico y fertilización nitrogenada. Revista Chapingo serie especial Horticultura. 17,13-18.

Medina, C. 2004. Normas DRIS preliminares para nogal pecanero. Terra. 22,445-450.

Nuñez-Moreno, H., Walworth, J.L., Pond., A.P., Kilby, M. 2009. Soil zinc fertilization of "Wichita" pecan tree growing under alkaline soil conditions. HortScience. 44,1736-1740.

Ojeda-Barrios D.L., J. Abadía, L. Lombardini, A. Abadía., S. Vázquez. 2012. Zinc deficiency in field-grown pecan trees: changes in leaf nutrient concentrations and structure. Journal of the Science of Food and Agriculture. 92,1672-1678. doi: 10.1002/jsfa.5530. 
Ojeda-Barrios, D.L., Perea-Portillo, E., HernandezRodríguez, O.A., Avila-Quezada, G., Lombardini, L., Abadía J. 2014. Foliar Fertilization with zinc in pecan trees. Hort Science 49, 562-566.

Palacco, J. C., Mazzatera, P., Tezzoto, T. 2013. Opinion: nickel and urease in plants: still many knowledge gaps. Plant Science. 79(90): 199-200.

Pond, A., Walworth, W.M., Kilby, J., Gibson, R., Call, R., Nuñez, H. 2006. Leaf nutrient levels for pecans. HortScience. 41,1339-1341.

Pradeep, W., Smith, M., Wood, B., Rohla, C. 2011. Response of Young bearing pecan tres to spring foliar nickel aplications. Journal of Plant Nutrition. 34(10): 1558-1566. DOI: $10.1080 / 01904167.2011 .585210$

Rahmana, H., Sabreenb, S., Alamc, S., Kawaic, S. 2005. Effects of Nickel on Growth and Composition of Metal Micronutrients in Barley Plants Grown in Nutrient Solution. Journal of Plant Nutrition. 28, 394-404.

Redjela, T., Sterckman T., Skiker S.,Echevarria, G. 2010. Contribution of apoplast and symplast to short term Ni uptake by maize and Leptoplax emarginata roots. Environ. Exper. Bot. 68, 99106.

Ruter, J.M. 2005. Effect of nickel applications for the control of mouse ear disorder on river birch. Hort Science. 23,17-20.

Seregin, I.V., Kozhevnikova, A.D. 2006. Physiological role of nickel and its toxic effects on higher plants. Russian Journal of plant physiology. 53 (2): 257-277. DOI: 10.1134/S1021443706020178
Smith, M.W., Cheary, B., Carrol, B. 2004. Response of pecan to nitrogen rate and nitrogen application time. HortScience. 39,1412-1415.

Wagle, P, Smith, M., Wood, B., Rohla, C. 2011. Supplemental Foliar Nickel and Copper Applications Do Not Reduce Kernel Necrosis in Pecan Trees Receiving Excess Nitrogen. Communications in Soil Science and Plant Analysis. 42,1238-1242. DOI: 10.1016/j. plantsci.2012.10.010

Witte, Claus-Peter. 2011. Urea metabolism in plants. Plant Science. 39, 431-438.

Wood, B. 2006. Correcting micronutrient deficiency using metal hyperaccumulators: Alyssum biomass as a natural product for nickel deficiency correction. HortScience. 41, 1231-1234.

Wood, B.W., Reilly, C.C., Nyczepir, A.P. 2004 a. Mouse-ear of pecan: I. Symptomology and ocurrence. HortScience. 38, 87-94.

Wood, B.W., Reilly, C.C., Nyczepir A.P. 2004 b. Mouse-ear of pecan: Influence of nutrient application. HortScience. 38, 95-100.

Wood, B.W., Reilly, C.C., Nyczepir, A.P. 2004 c. Mouse-ear of pecan: a nickel deficiency. HortScience. 39, 1238-1242. 